\title{
Legislasi hukum Islam dalam perspektif produk perundang-undangan di Indonesia: integrasi antara maqāṣid al-shari' 'ah dengan tujuan legislasi
}

\author{
Mudzakir \\ Sekolah Tinggi Agama Islam Negeri Kudus
}

The challenge in the implementation of Islamic laws faced by Indonesian Muslims has not to do with the struggle for recognition by national laws. Instead, it deals with effort to clarify their position among various social groups. It also examines how much Islamic laws contribute values that stimulate development, order, peace and welfare for the nation and country. Historically, qur'anic verses in concerning with legal were revealed mostly after the Messenger migrated to Medina, while Meccan verses are identified as to consolidate the ummab so that they were ready to bear the burden imposed by the Islamic laws (takliff). The regulations reflecting shari'ah laws issued by the local governments and their implementation tend to be euphoric taking the chance given by the reform. They have not reflected different social groups on which the regulations will be imposed. Islamic laws as the basic consideration in formulating the local government regulations seem not to have accommodated religious elements comprehensively, i.e. integrating 'aqidah, akblāq and shari'ah guiding people's behavior conceptually as well as in practice. Therefore, partial implementation of Islamic shari ${ }^{\prime} a b$ will result in pseudo-religiousity, and tend to become a problem for the ummab themselves.

Keywords: Legislation; Islamic law; Religious comprehensive; Mașälị ummah.

\section{Pendahuluan}

Kata legislasi (al-tashrï) hukum Islam merupakan istilah teknis tentang pembentukan hukum (figh) atau peraturan perundang-undangan, di dalamnya melingkupi produk dan proses pembentukan hukum (fiqh), bisa berarti tashri $\bar{i}^{\prime}$ dari sumber hukum, dan tashri $\bar{r}^{\prime}$ dari dimensi pengembangan. Tasbri dari sumber hukum berarti pembentukan hukum, otoritas untuk 
Ijtihad, Jurnal Wacana Hukum Islam dan Kemanusiaan, Vol. 11, No. 1, Juni 2011: 21-39

dimensi ini hanya dimiliki oleh Rasulullah saw. pada waktu itu. Sedangkan tashri ${ }^{\prime}$ dalam arti pengembangan (kandungan dan keluasannya) bersifat insaniyah (ijtihädijaab), otoritasnya dimiliki oleh para sahabat dan ulama sesudahnya, baik dalam bentuk hukum fikih atau peraturan perundang-undangan baik yang penerapan memerlukan keterlibatan negara maupun tidak.

Sejarah tentang polemik penerapan hukum Islam di Indonesia, berkaitan erat dengan polemik hubungan antara agama dengan negara, seperti terjadi antara Soekarno, H. Agus Salim, A. Hasan, dan Mohammad Natsir mengenai implementasi hukum Islam menjadi hukum publik, bahkan sebagai dasar negara Indonesia, sudah dimulai semenjak menjelang kemerdekaan Indonesia (Noer, 1996: ix-xx), pasca kemerdekaan (Boland, 1985: 171-181), bahkan sampai dengan sekarang polemik tersebut masih terjadi dengan mempermasalahkan perda-perda bernuansa syariah, dengan berbagai alasan masing-masing.

Bagi umat Islam, berpikir dengan memposisikan agama dan negara sebagai hal yang das ding an sich pada entitas masing-masing, berarti telah melupakan sejarah, ketika Rasulullah mendirikan Negara Madinah. Bukankah Islam sebagai agama diturunkan oleh Allah dimaksudkan untuk mengurus keseluruhan kehidupan di muka bumi ini? Bila dipetakan dengan menggunakan tipologi yang dibuat John F Haught, maka pemikiran dikotomis tersebut telah menyeret kepada tipologi konflik yang seharusnya tidak boleh terjadi (Kuswanjono, 2010: 51-63).

Sebagai bagian dari ontologi fikih yang epistemologinya mengakui berbagai paradigma dan metodologi serta penerapannya, sesungguhnya menjadi fleksibilitas dan ekstensitas fikih dalam menghadapi dan menyelesaikan masalah aktual (furū') (Djamil, 1997: 46-51). Karena sesungguhnya kebenaran fikih diukur dari dimensi epistemologi dan aksiologi yang produktif dalam ruang dan waktu tertentu.

Konsekuensi logis munculnya variasi pendapat dan corak pemikiran dalam menyikapi hubungan syariah dan negara setidaknya ada empat varian: Pertama, kelompok yang menghendaki hukum Islam sebagai kultur masyarakat Indonesia untuk mengatur pemeluknya, varian ini didukung para ulama tradisional yang berafiliasi pada paham ideologi politik konservatisme-tradisional. Kelompok ini berpandangan bahwa agama dan negara tidak terpisah serta Islam merupakan agama yang menawarkan pemecahan terhadap semua masalah kehidupan. Islam diyakini sebagai agama yang käffah meliputi din, dunyā, dan dawlah 
(Syamsudin, 2001: x).

Kedua, kelompok moderat-konstitusional yang menginginkan adanya kesatuan dan keseragaman hukum. Agama merupakan salah satu sumber hukum dalam pembentukan hukum nasional (Ayubi, 1991: 63-64). Paradigma berpikir kelompok ini adalah menjaga hubungan yang seimbang antara syariah dan negara. Pada kondisi tertentu perlu dilakukan formalisasi hukum Islam dalam perundang-undangan negara, pada saat yang lain Islam diposisikan sebagai sumber etika-moral. Ketiga, kelompok liberal-sekularistik yang tidak menginginkan berlakunya hukum Islam secara terlembaga dan bahkan ada kecenderungan menyingkirkan hukum Islam, mereka terdiri dari orang-orang nasionalis-sekuler dan didukung oleh orang-orang non-muslim (Halim, 2008: 8-10). Kemudian yang ke-empat adalah kelompok fundamentalis-skriptualis dengan gerakan purifikasi dan reformasi yang awal mulanya dimotori oleh kaum Padri di Tanah Minangkabau dengan jargon "gerakan kembali ke syariah" (http.//1.bp.blogspot.com, diakses tgl. 22 Juni 2010). Mereka berusaha membasmi praktik-praktik keagamaan yang dianggap bid'ah, khurafat dan bertentangan dengan Islam. "Karena itu harus diluruskan, atau bahkan jika diperlukan, harus diperangi dengan jalan kekerasan" (Wahid, 2009: 76-77). Bersama dengan kelompok lain yang sealiran, berusaha mendirikan negara Islam "Khilafah Islamiyah" dengan syariah Islam sebagai hukum positifnya.

Kaitannya formalisasi hukum Islam, Nurcholis Madjid mempetakannya menjadi kelompok masyarakat substansialistik yang berpandangan "hukum Islam tidak perlu diformalisasikan" dan kelompok masyarakat formalistik yang berpendapat bahwa "hukum Islam perlu diformalisasikan menjadi hukum publik untuk mendapatkan dan menjamin adanya kepastian hukum" (Rahman, 2006: 7-8). Kelompok formalis ini berpegang pada suatu prinsip "hukum tanpa kekuasaan adalah angan-angan belaka, kekuasaan tanpa hukum adalah kelaliman” (Mertokusumo, 1999: 16).

Ontologi masing-masing kelompok memiliki epistemologi sendiri-sendiri, dan wujud akhir (aksiologi)-nya juga menjadi tidak selalu sama dan karenanya tidak tepat jika dipertentangkan, khususnya berkaitan dengan formalisasi hukum Islam di Indonesia. Tulisan singkat ini dimaksudkan memberikan kontribusi bagi kelompok yang cenderung adanya formalisasi hukum Islam, yang substansinya harus dilihat secara utuh dengan 
ljtihad, Jurnal Wacana Hukum Islam dan Kemanusiaan, Vol. 11, No. 1, Juni 2011:21-39

mempertimbangkan aspek teologis, sosiologis maupun filosofisnya untuk lebih mempertajam produktifitas sebuah undang-undang atau perda bernuansa syariah dalam bermasyarakat, berbangsa dan bernegara di Indonesia yang memiliki karakteristik pluralis. Penegakan syariah Islam dengan melepaskan konteks keberagamaan secara utuh, dalam pengertian hukum Islam an sich, sudah pasti hanya akan melahirkan problematika baru, baik bagi hubungan agama-negara maupun bagi agama Islam itu sendiri (Audah, 2008: xxvii).

Tulisan ini juga tidak bermaksud menegasikan pemberlakuan syariah Islam kelompok substansialis, yang lebih memilih pola internalisasi ajaran Islam menjadi sebuah kultur masyarakat, sebuah pola evolutif yang mengintegrasikan ajaran Islam dengan budaya setempat. Untuk itu, kajian tentang relevansi teori maslahạh sebagai inti maquasid al-shari'ah dengan penerapan syariah Islam, memiliki nilai signifikan dan kontributif bagi upaya pembentukan pranata sosial dalam konteks ke-Indonesia-an sekaligus kemodernan (baik pola substansialis maupun formalis), yang secara substantif juga bermakna sebagai upaya penyadaran masyarakat akan tugas dan kawajibannya sebagai warga bangsa.

Lebih jauh, dapatlah dikatakan bahwa tantangan utama bagi umat Islam dalam upaya penerapan syariah Islam adalah memperjelas posisi hukum Islam dalam keberagamaan secara utuh; bukan sekedar mencari legitimasi hukum Islam atas hukum nasional, tetapi mengerahkan seberapa banyak hukum Islam mampu menyumbangkan nilai-nilainya dalam rangka kemajuan, keteraturan, ketenteraman dan kesejahteraan dalam kehidupan berbangsa dan bernegara sebagai bagian dari beragama (Azizy, 2002: 176-177). Hal ini menuntut kajian yang mendalam seputar hukum Islam, yang salah satunya ialah pengkajian titik temu konsep maslahạ dalam hukum Islam ke dalam norma hukum positif (perda bernuansa syariah).

\section{Konsep maṣlaḥạ̣ dalam hukum Islam}

Universalitas hukum Islam meniscayakan ketundukan semua pemeluk Islam pada ajaranajaran agama Islam, di manapun dan kapanpun mereka berada, dan juga meniscayakan adanya nilai-nilai universal yang terkandung di dalam hukum-hukum cabangnya (furü (íyyah) yang mungkin berbeda antara satu tempat dan tempat lainnya atau pada satu tempat yang sama tetapi terjadi pada waktu yang berbeda (Mawardi, 2010: 2). 
Perumusan hukum Islam sebagai bagian term "keberagamaan" menunjuk pada respon terhadap wahyu, baik dalam kawasan konseptual maupun pelaksanaan ajaran, karenanya Joachim Wach mengajukan istilah "pengalaman keagamaan”. Dengan kriteria: Pertama, merupakan tanggapan terhadap sesuatu yang dihayati dari Realitas Mutlak. Kedua, dalam tanggapan ini, pribadi utuh yang terlibat dalam kegiatan, bukan sekedar pikiran, perasaan atau kehendak semata. Ketiga, adanya kedalaman tertentu. Kriteria keempat, adalah ungkapan pengalaman tersebut dalam perbuatan. Cakupan ungkapan pengalaman dalam perbuatan ini meliputi pemikiran, perbuatan dan kehidupan kelompok (Wach, 1994: 44).

Rumusan terminologi "keberagamaan" yang dikemukakan oleh Wach di atas pada prinsipnya sama dengan rumusan tentang iman oleh al-Asy'ari. Menurut Imam Al-Asy'ari iman yang merupakan bagian dari keberagamaan dalam Islam meliputi tiga unsur, yaitu: tașdiq bi al-qalb, taqür bi al-lisān dan 'amal bi al-arkān (al-Syahratsani, t.th.: 101). Jika diukur dari wujud kenyataan yang ditunjuk oleh pengertian keberagamaan menurut Wach dengan iman menurut al-Asy'ari, maka pendapat kedua sarjana ini adalah identik. Menurut R. Stark dan CY. Glock keberagamaan manusia itu dibagi menjadi lima dimensi, yaitu keyakinan, praktek, pengalaman, pengetahuan dan konsekuensi-konsekuensi (Robertson, 1995: 295). Dalam kenyataan empirisnya, antar dimensi keberagamaan tersebut saling terkait dan membentuk sebuah perilaku keberagamaan.

Wujud pelaksanaan ajaran Islam yang diistilahkan dengan "pengalamanan keagamaan" menurut para sarjana tersebut sesungguhnya ekuivalen dengan "integrasi akidah, akhlak dan syariah" (Ali, 1999: 28) yang mengatur perilaku manusia baik pada tingkat konseptual maupun aktualnya.

Hukum Islam adalah merupakan salah satu unsur beragama yang berupa seperangkat norma untuk mengatur seluruh tingkah laku praktis ('amali) manusia atau dalam literatur Islam sering disebut dengan figh. Pengertian tersebut antara lain merupakan pendapat Muhammad 'Abduh yang memberikan pengertian syariah demikian luas ('Abduh, 1967: 24). Berbeda dengan 'Abdul Wahab Khalaf yang membagi hukum-hukum dari al-Qur'an menjadi tiga: aḅkeam i tiqädiyah, ạ̣kam khuluqiyah, dan ạ̣kam 'amaliyah (Khalaf, 1985: 38).

Hukum Islam, sebagai suatu sistem hukum yang berdasarkan wahyu, memiliki tujuan mewujudkan kemaslahatan manusia di dunia dan kebahagiaan di akhirat. Untuk mengantarkan 
ljthad, Jurnal Wacana Hukum Islam dan Kemanusiaan, Vol. 11, No. 1, Juni 2011:21-39

terwujudnya tujuan tersebut, Allah (Shäri') menganugerahkan tuntunan, untuk mengatur hubungan manusia dengan Tuhannya, hubungan manusia dengan sesama manusia, dan hubungan manusia dengan alam sekitarnya, serta mengatur dirinya sendiri, baik pada domain akidah, akhlak maupun ibadah (mabdah dan mu'amalab).

Sumber aturan pada masing-masing domain tersebut berupa wahyu (sumber qauliyah berupa al-Qur'an dan Hadis dan sumber kawniyab berupa alam). Ungkapan dalam al-Qur'an dan Hadis sebagian bersifat tafsili dan sebagian yang lain bersifat ijmäli, ada yang memiliki daya ikat dan validitas yang kuat ( $q a t^{\bar{\imath}}$ ) adapula yang longgar (zannī). Hal-hal yang telah diatur secara qat $t_{i} \overline{\text { dan }}$ muqaddarät di dalam nas, mayoritas ahli usul sepakat tidak melakukan perubahan dan pengembangan (ijtihad), hal ini didasarkan pada sebuah hadis nabi riwayat Ibn al-Qasim ibn Muhammad Man aḥdatha fí amrinā bädhā mä laysa fíbi fa buna radd (alBukhary, Vol. II, t.th: 112). Hadis tersebut mencakup bidang aqidah, ibädah mabdah dan halhal yang sifatnya sudah ditentukan (muqaddarä).

Berbeda dengan masalah-masalah tersebut di atas, masalah $m u$ 'amalah atau sosial kemasyarakatan dalam arti luas, aturan hukumnya dituangkan oleh Allah dalam bentuk ïmäli dan bersifat zanni. Bertitik tolak dari garis-garis besar tersebut, para mujtahid dengan potensi dan kualifikasinya, diberi kewenangan untuk mencari alternatif-alternatif pemecahan terhadap permasalahan mu'amalah atau sosial kemasyarakatan dalam arti luas itu. Salah satu alasannya adalah untuk merealisasikan kemaslahatan manusia yang bersifat dinamis seiring perkembangan dan kemajuan budaya masyarakat.

Dalam perspektif pemikiran hukum Islam (ușül al-fiqh) para ulama usul dalam berijtihad secara garis besar menerapkan dua pola berpikir, yaitu pola berpikir deduktif dan induktif untuk mewujudkan kemaslahatan tersebut di atas - pada aturan hukum yang dituangkan oleh Allah dalam bentuk ijmäli dan bersifat zanni. Metode-metode itu antara lain qiyās, istibsān, istịlăh, istishāb, maslahạh mursalah dan 'urf dalam bingkai maqāsid al-sharì'ah. Metode-metode ini memang menjadi perdebatan di kalangan ahli usul, tetapi sejatinya justru merupakan "peluang" untuk menyelesaikan berbagai permasalahan mu'amalab dan sosial kemasyarakatan yang belum mendapatkan justifikasi dalil hukum secara tegas oleh nas, dengan merumuskan kembali metodologi legislasi hukum Islam (umpamanya konseptualisasi dan kontekstualisasi maslahạh) dalam bidang tersebut. Menurut istilah, maqāsid al-shari'ah adalah al-ma'ani allatī 
Legislasi hukum Islam dalam perspektif produk perundang-undangan di Indonesia:... (Mudzakir)

shuri'at labā al-ahleam "kandungan nilai yang menjadi tujuan pensyariatan hukum".

Imam Maliki (w $179 \mathrm{H})$ menerima al-masăäh al-mursalah sebagai salah satu metode istinbät al-hukm. Dengan metode ini, seseorang bisa "berkreasi" menentukan hukum sesuatu yang tidak ditegaskan oleh nas dan tidak ditolak olehnya (mursalah mutlaqah) selagi memenuhi kreteria darüriyyät, kulliyyat dan nyata-nyata mendatangkan kemaslahatan dalam lingkup pemeliharaan atas lima hal pokok (al-kulliyyät al-khams). Para ulama usul mengklasifikasikan mașlahạ dalam tiga tipologi: 1) maslahạ mu'tabarah, yaitu maslahah yang keberadaannya dibenarkan oleh nas, 2) mașlahạ mulghah, yaitu maslahạ yang keberadaannya nyata-nyata tidak dibenarkan oleh nas. 3) maslahạ mursalab atau mutlaqah, yaitu maslahah yang tidak terdapat dalam nas, baik yang menerima maupun yang menolaknya. Tipologi yang ketiga inilah yang menjadi ladang garapan kalangan Malikiyah.

Pandangan imam mazhab di atas terhadap maslahah juga diikuti oleh para ulama sesudahnya, seperti al-Juwayni (w $478 \mathrm{H}$ ), al-Ghazali (w $505 \mathrm{H}$ ), Ibn Taymiyah (w $661 \mathrm{H}$ ), Najm al-Din al-Tufi (w 716 H), Ibn Qayyim al-Jauzi (w 751 H), al-Syatibi (w 790 H) bahkan para ilmuwan kontemporer semacam Fazlurrahman, Abdullahi Ahmed al-Na'im, Jassir Auda dan masih banyak lagi, walaupun mereka kemudian menambahkan beberapa kreteria dan syarat dalam aplikasinya.

Secara lughawiyah, maslaḥa ș sama dengan manfa'ab baik dari bentuk katanya (wazn) maupun maknanya. Dalam terminologi usul fikih, maslaḥạ̣ diartikan segala sesuatu yang dapat mewujudkan kebaikan dan terhindarnya segala macam madarah atau mafsadab dalam kehidupan manusia (Al-Ghazali, 1994: 286). Dengan demikian, barometer ada tidaknya maslahạ diukur dengan dua hal tersebut. Bila tercipta kebaikan berarti maslahah, sebaliknya, bila terjadi bahaya, ketimpangan, kerusakan, ketidak-adilan dan sebagainya berarti terjadi mafsadah atau madarah.

Generasi berikutnya, al-Syatibi dari golongan Malikiyah - seorang fuqaha yang hidup hampir semasa dengan Ibnu Taymiyah (w $661 \mathrm{H}$ ) dan Ibnu Khaldun (w $732 \mathrm{H}$ ). Dalam kitabnya Al-Muñäagätfi Ușül al-Sharìah, al-Syatibi memformulasikan sedemikian rupa konsep maslạah yang dirintis al-Juwaini dan al-Ghazali, dan menjadikannya sebagai metode istinbät al-ḥukm di kalangan Malikiyah, yakni metode maslahah mursalah yang konseptualisasinya masih sangat terikat dengan teks. Mirip al-Ghazali, al-Syatibi membagi maqāsid menjadi dua, dan menegaskan bahwa maqāsid al-mukallaf tidak boleh menabrak rambu-rambu maqāsid al- 
Ijtihad, Jurnal Wacana Hukum Islam dan Kemanusiaan, Vol. 11, No. 1, Juni 2011: 21-39

Shäri', keduanya harus sesuai, dan apabila terjadi pertentangan antara keduanya, maka yang harus dikalahkan adalah maqāsid al-mukallaf.

Masalahnya, bagaimana menangkap kehendak Tuhan melalui wahyu-Nya yang ada pada ranah metafisik-transendental dan menterjemahkannya untuk menjawab kehidupan empirispraktis yang harus melewati garis demarkasi antara wilayah metaphisik-transendental memasuki wilayah empiris-praktis, dan konseptualisasi para ahli usul klasik yang telah melewati (trans) sejarah panjang kepada konseptualisasi dalam konteks sekarang di Indonesia?

Ilustrasi metodologi yang dikembangkan oleh al-Syatibi adalah menetapkan kerangka acuan (frame work) yang merupakan tujuan esensial hukum Islam yang bersifat universalsubstansial, seperti menegakkan keadilan (al-Nahl 16: 90.), memelihara amanah (al-Nisa', 4: 58), mewujudkan kemaslahatan umum (al-Hujurat, 49: 9-10), dan semacamnya. Ayat-ayat substansial-universal (kulliyyät) inilah yang akan membingkai pembacaan ta 'lil ayat-ayat singular (juz'iyyät) dan kemaslahatan empiris pada posisi scondness (al-diyanab) yang selalu mengalami perubahan (change). Langkah berikutnya diperlukan development sebagai upaya menemukan thirdness (al-tadayyun) dengan membangun intersubjective sebagai jawaban kemandegan maslaḥa ḥ hukum Islam dalam menyelesaikan setiap permasalahannya.

Jika langkah perumusan norma universal telah terlampaui, maka langkah berikutnya menjabarkan (break down) norma universal tersebut menjadi ketentuan-ketentuan spesifik dan lokal yang bersifat singular atau partikular. Dimensi ini masuk kategori ilmu-ilmu praktis maslahạh dalam hukum Islam pada ranah empiris (al-diyanab dan al-tadayyun) yang tidak bisa dilepaskan dari kontek sosio-religius masyarakat pada zaman dan tempat tertentu. Rumusan ketentuan-ketentuan maslahạ dalam hukum Islam yang bersifat empiris-praktis ini bentuk (form)-nya tidak mesti sama dalam merespon karakteristik zaman dan tempat suatu masyarakat, tetapi esensi (universalitas) tujuannya harus sama dalam bingkai maqāsid al-sharì'ah.

Dalam kaitan ini, bisa memanfaatkan kaidah-kaidah fikih seperti: al-ádah mubakkamah (Al-Sayuthiy, 1975: 122), taghayyur al-ahkeam bi al-taghayyur al-azmān wa al-amkinab, untuk mengakomodasi tradisi dan adat istiadat wilayah dan zaman tertentu selama tidak menyimpang dari maqūsid al-shari ${ }^{\prime} a h$-nya. Konsekuensi filosofis-metodologis dari kerangka pikir tersebut adalah bahwa pada ranah historisitas dimungkinkan terbentuknya perbedaan konsep maslaḥạ̣ dan aktualisasinya pada wilayah dan bahkan antar waktu tertentu. 


\section{Posisi hukum Islam dalam politik hukum di Indonesia}

Terminologi hukum Islam sebagai bagian beragama, dikonseptualisasikan dari sumbernya, antara lain dalam surat al-Māi idah 5: 48; al-Shürā 42: 13; dan al-Jāthiyah 45: 18, merupakan pesan universal wahyu Allah, ajarannya diperuntukkan kepada semua penghuni alam semesta tanpa membedakan suku, agama, ras dan budaya, agar terwujud "rahmat bagi semesta". Respon ajaran tersebut menjadi bagian dari keberagamaan (al-tadayyun) manusia yang pemaknaan dan pelaksanaannya akan selalu dipengaruhi daya intelektual dan dinamika budaya serta tradisi para pemikirnya (buman construction) pada wilayah dan zaman tertentu (Abdullah, 1996: 9). Konsekuensi metodologis dari kerangka pikir tersebut adalah bahwa pada ranah historisitas dimungkinkan terbentuknya perbedaan konsep dan pelaksanaan hukum Islam antar wilayah dan bahkan antar waktu tertentu.

Sebagai hasil pemikiran, bila syariah Islam itu dikonsepsikan sebagai bangunan ilmu pengetahuan (the body of knowledge), maka obyek materinya dapat dibedakan menjadi: 1) Sumber utama syariah yang memiliki "kebenaran transendental/ilabiyab"; 2) Kaidah syariah yang berlaku universal/kulli, 3) Rumusan normatif-praktis syariah Islam yang bersifat singular/juz $\bar{i}$, serta 4) Implementasi syariah Islam bersifat kontekstual/ amali (Djamil, 1997: 1617). Dalam hukum Islam sendiri tidak ada pemilahan secara rigid antara public law dengan private law sebagaimana hukum Romawi. Skema pemilahan yang digunakan adalah: aḅkam i'tiqädiyah; ạ̣keàm khuluqiyah; dan ạ̣kām 'amaliyah (Khalaf, 1972: 22). Josep Schacht, mengklasifikasikannya menjadi "Hak Tuhan" dan "Hak manusia" yang tidak ada sangkut pautnya dengan hukum publik dan hukum perdata. (Schacht, 1959: 139). An-Na'im menggunakan terminologi "hukum publik syariah" sebagai istilah umum untuk aspek-aspek syariah yang diterapkan atau diandaikan penerapannya dalam kehidupan publik masyarakat Muslim (An-Na'im, 1994: 14). Sedangkan obyek forma syariah Islam, berupa metodologi yang ditempuh para mujtahid dalam memahami sumber syariah Islam, yang kemudian dikenal sebagai the fundamental theory of Islamic Law.

Sejarah mencatat bahwa hukum Islam sesungguhnya telah menjadi bagian pranata sosial setidaknya sampai akhir abad ke-19 M. Munculnya teori Receptio in Complexu yang dikembangkan oleh Van den Berg (1885-1927), memberlakuan hukum Islam sejajar dengan sistem hukum lainnya. Seiring dengan kepentingan politik, Belanda mulai melakukan 
ljtihad, Jurnal Wacana Hukum Islam dan Kemanusiaan, Vol. 11, No. 1, Juni 2011:21-39

penyempitan bagi ruang gerak dan perkembangan hukum Islam, melalui konsep Het Indiche Adatrecht dengan tokohnya Van Vollenhoven (1874-1933) dan C.S. Hurgronje (1857-1936) dan melahirkan teori Receptie. Klaim profokatif dan distorsif ini sangat berpengaruh terhadap eksistensi hukum Islam ketika itu, bahkan hingga sekarang orang selalu curiga terhadap pemberlakuan hukum Islam. Karenanya sangat wajar apabila Hazairin menyebut teori Receptie ini sebagai "teori iblis". Masa pascakemerdekaan, ditandai banyaknya teori hukum sebagai counter theory terhadap teori Receptie, paling tidak ada tiga teori: Pertama, teori Receptie Exit, yang dikemukakan oleh Hazairin, yang menyatakan bahwa teori Receptie harus exit (keluar) dari teori hukum Islam di Indonesia. Kedua, teori Receptio a Contrario yang dikemukakan oleh Sayuti Thalib, yang menyatakan bahwa hukum yang berlaku bagi rakyat Indonesia adalah hukum agamanya, hukum adat hanya berlaku jika tidak bertentangan dengan hukum agama. Ketiga, teori Existence, yang dikemukakan oleh Ichtijanto, yang memperkuat teori Receptio a Contrario dalam hubungannya dengan hukum nasional. (Fuad, 2005: 48-56).

Dalam studi politik hukum, sebagaimana tercantum dalam Pembukaan Undang Undang Dasar 1945 (Mahfud, 2010: 1), para founding fathers negara Indonesia telah menentukan pilihan sistem pemerintahan negara, bahwa negara Indonesia berdasar atas hukum (rechstaat) tidak berdasar atas kekuasaan belaka (machtsstaat) serta pemerintahan berdasar atas sistem konstitusi (hukum dasar) tidak bersifat absolutisme. Dalam membangun negara hukum (rechstaat) didasarkan atas empat prinsip: kepastian hukum, persamaan, demokrasi dan pemerintahan yang melayani kepentingan umum (bet beginsel van dienende overhead) akan dijadikan acuan utama (Adji, 1980: 24-58).

Meskipun dalam penjelasan Undang Undang Dasar 1945 digunakan istilah rechstaat, namun konsep rechstaat yang dianut oleh negara Indonesia bukan konsep negara Barat (Eropa Kontinental) dan bukan pula konsep rule of law (Anglo Saxon). Konsep negara hukum Indonesia berdasarkan Pancasila, bercirikan adanya hubungan yang erat antara agama dan negara, adanya jaminan terhadap freedom of religion bertumpu pada Ketuhanan Yang Maha Esa, kebebasan beragama dalam arti positif, tidak membenarkan atheisme, melarang komunisme serta berdasar asas kekeluargaan dan kerukunan (Sirajuddin, 2008: 3-4).

Dalam perjalanan sejarah ketatanegaraan bangsa Indonesia, seringkali menunjukkan adanya "hubungan hukum dengan politik" yang dinamis atas dasar prinsip-prinsip yang diamanatkan 
Legislasi hukum Islam dalam perspektif produk perundang-undangan di Indonesia:... (Mudzakir)

dalam Undang Undang Dasar 1945. MPR sebagai badan untuk mewujudkan kehendak rakyat menetapkan Undang Undang Dasar dan sekaligus memiliki otoritas politik hukum, melalui mekanisme musyawarah. Kesepakatan dalam lembaga MPR itulah, dalam sejarahnya menunjukkan adanya pergumulan "hukum dengan politik", dan upaya mewujudkan suatu produk hukum ternyata tidak steril dari subsistem kemasyarakatan lainnya (Mahfud, 2010: 9).

Jika di kalangan umat Islam sendiri masih berpolemik mengenai formalisasi syariah Islam, maka beban perjuangan umat Islam menjadi bertambah, yaitu legislasi hukum Islam menjadi undang-undang (seperti perda bernuansa syariah) yang belum mengintegrasikan prinsip-prinsip dasar dan hakekat hukum Islam sebagai bagian keberagamaan secara utuh (An-Na'im, 1997: 1-20). Maka pemikiran Qadri Azizy perlu mendapatkan perhatian, khususnya bagi umat Islam, bahwa upaya penerapan hukum Islam di Indonesia adalah memilih alternatif pemikiran yang lebih dipandang produktif dari kelompok substansialis dan atau formalis dalam menegakkan hukum Islam, teknisnya bisa berbeda namun prinsip universalnya harus sama, yaitu mewujudkan kemaslahatan bersama dalam bermasyarakat, berbangsa dan bernegara.

\section{Konseptualisasi dan kontekstualisasi maṣlạ̣ạ̣ ke dalam perda}

Secara konseptual, mașlạ̣aḥ menurut al-Ghazali adalah suatu keadaan yang mendatangkan manfaat dan menolak bahaya atau kerugian (al-Ghazali, 1994: 481). Al-'Izz bin 'Abd alSalam menyatakan bahwa mașlạ̣ạ̣ sebagai jiwa hukum Islam harus mendatangkan manfaat dan menolak mafsadat, berarti terdapat suatu keyakinan bahwa pada setiap ketentuan hukum Islam terdapat maslahạ dan sekaligus menghilangkan mafsadah, sekalipun tidak terdapat dalil yang khusus (al-Salam, 1986: 160). Sedangkan al-Syatibi berpendapat bahwa mașlạ̣ạ̣ sebagai inti dari maqäsid al-shari'ah bertujuan untuk menjaga tiga gradasi kebutuhan manusia (darüriyyät, hạjizyyät dan taḥsiniyyāt) dan Allah sebagai Shäri memiliki tujuan yang inheren dalam setiap penentuan hukum-Nya, yaitu kemaslahatan hidup di dunia dan akhirat (alSyatibi, 2004: 221).

Terlepas dari perbedaan tentang konseptualisasinya, para ulama usul sepakat bahwa maslaḥạ merupakan tujuan akhir yang harus wujud dan mengilhami serta membimbing para ahli hukum Islam (termasuk para legislator) dalam merumuskan hukum Islam khususnya 
ljtihad, Jurnal Wacana Hukum Islam dan Kemanusiaan, Vol. 11, No. 1, Juni 2011:21-39

bidang mu'amalah seperti perumusan sebuah perda bernuansa syariah. Konseptualisasi maslaḥạ itu sendiri bersifat dinamis yang memungkinkan mengakomodasi kemaslahatan ('urf) atau tradisi lokal, sehingga unsur-unsur esensial maslạạ bisa bertemu dengan esensi tujuan perda. Dengan demikian maslahah yang telah terintegrasi ke dalam perda akan menjadi pranata sosial yang tanggap dengan kebutuhan masyarakat itu.

Legislasi perundang-undangan di Indonesia, adalah upaya pembuatan hukum yang dilakukan secara sengaja oleh badan yang berwenang untuk itu (Rahardjo, 1996: 83). Proses legislasi secara komprehensif dan integrated semakin terasa diperlukan kehadirannya, oleh karena di dalam negara yang berdasarkan atas hukum modern (verzorgingsstaat), tujuan utama dari pembentukan peraturan perundang-undangan bukan lagi menciptakan kodifikasi bagi norma-norma dan nilai-nilai kehidupan yang sudah mengendap dalam masyarakat, akan tetapi tujuan utamanya adalah menciptakan modifikasi adanya perubahan pada kehidupan sosio-religius masyarakat Indonesia yang sedang menghadapi prilaku yang tidak religius.

Pada dasarnya UUD 1945 mengatakan bahwa negara menjamin kebebasan warganya dalam menjalankan ajaran agamanya. Klausul ini bisa berarti bahwa orang Islam dijamin kebebasannya di dalam menjalankan ajaran agama Islam, dalam konteks Negara kesatuan Republik Indonesia (NKRI) dengan tetap menjaga kebhinekaan. Oleh karena itu, diperlukan metodologi konseptualisasi hukum Islam yang mampu mengakomodasi norma-norma kebhinekaan tersebut dari pesan universalnya yang tercantum dalam al-Qur'an dan hadis. Rumusan empiris-praktis dari pesan universal tersebut pada wilayah dan zaman tertentu tidak menuntut adanya keseragaman, selama masih dalam koridor tujuan disyari'atkannya hukum Islam (maqāsid al-shari'ah) untuk mewujudkan kemaslahatan yang bersifat lokal (Indonesia).

Orang Islam percaya bahwa orang yang mencuri akan dipotong tangannya, demikian terhadap orang yang berbuat zina, mereka harus dirajam, orang yang membunuh harus diqisos, demikian juga prostitusi, korupsi dan sebagainya. Meski demikian, penting untuk dicatat bahwa semua jenis hukuman tersebut harus berujung pada terwujudnya kemaslahatan empiris yang selaras dengan pesan universal hukum Islam. Dalam konteks negara Indonesia sebagai negara hukum, jika ada orang Islam yang memotong jari anaknya yang mencuri atau menghukum rajam orang yang mengaku berbuat zina, alih-alih mereka telah melaksanakan 
dan mentaati hukum Islam, tetapi yang bersangkutan bisa dianggap melanggar hukum positif yang berlaku. Untuk menghindari hal yang demikian dan agar terdapat keserasian antara berbagai sumber norma, menjadi norma hukum, negara perlu ikut mengarahkan dan mengatur kehidupan beragama dalam konteks ke-Indonesia-an.

Contoh lainnya adalah perda-perda yang telah diberlakukan di Indramayu, Pamekasan dan Gresik. Sekalipun perda-perda ini secara eksplisit tidak menggunakan kalimat syariah, tetapi perda itu mengatur persoalan agama dan quasi-peradilan. Hal tersebut belum diarahkan pada upaya penegakan agama secara utuh, baik dimensi materi, prosedur, maupun historisnya. Dari dimensi materi dan prosedur, sebuah perda harus mengintegrasikan akidah dan akhlak untuk mengatur perilaku manusia baik pada tingkat konseptual maupun aktualnya. Menurut Nurcholis Madjid, keberagamaan yang utuh terdiri dari fikih, kalam, tasawuf, dan falsafah Islam, seperti yang secara aktual berkembang pada masa Rasulullah dan masa sahabat yang memberlakukan hukum Islam setelah memantapkan dimensi akidah, akhlak, dan ibadah sosial-religius masyarakat selama lebih-kurang 10 tahun di Makkah. Sejarah mencatat, ayatayat hukum lebih banyak turun setelah Rasulullah hijrah ke Madinah, sementara itu ayat-ayat Makkiyah teridentifikasi dalam kerangka konsolidasi agar umat siap menerima beban hukum (taklif) seberapa berat taklif itu.

Lahirnya perda-perda bernuansa syariah dengan teknik-teknik pelaksanaannya di Indonesia karenanya dikatakan bersifat "euforis" karena belum mempersiapkan keberagamaan umat untuk siap menerima ketentuan hukum dalam perda-perda itu. Bahkan struktur syariah Islam sebagai ide dasar legislasi perda-perda itu, belum diakomodasi secara komprehensif termasuk kaidah-kaidah universal yaitu konsep maslahạh sebagai inti maqăsid al-sharì'ah dengan tujuan legislasi hukum Islam.

Secara hipotetik, bila unsur-unsur tersebut bertemu dan diakomodasi dalam sebuah pranata sosial (perda), maka hasilnya akan lebih produktif untuk masyarakat yang mayoritas beragama Islam. Bagaimana prosedur integrasi berbagai unsur tersebut, pemilihan teorinya telah mempertimbangkan secara filosofis tentang hakekat keberadaan antara Allah swt., akal, dan alam semesta - termasuk fenomena sosialnya (Kadir, 2011: 1-11). 
Ijtihad, Jurnal Wacana Hukum Islam dan Kemanusiaan, Vol. 11, No. 1, Juni 2011: 21-39

\section{Titik temu maqāṣid al-Sharỉ'ah dengan tujuan legislasi hukum Islam}

Memahami hukum Islam seperti tersebut di atas, dalam perspektif politik hukum, hukum Islam diposisikan sebagai hukum adat (common law), tidak dapat sama sekali diabaikan, sekalipun suatu negara telah memakai sistem hukum perundang-undangan. Pada sebagian masyarakat, hukum Islam telah bergeser menjadi sebuah idiologi, melalui proses idiologisasi yaitu sebuah usaha mengorganisasi isi ajaran agama pada agama-agama modern. Peraturan daerah adalah salah satu proses unifikasi hukum untuk suatu wilayah atau daerah tertentu menjadi ketentuan-ketentuan hukum yang spesifik dan praktis (kodifikasi hukum), mesti mengakomodasi sumber hukum tidak tertulis seperti posisi hukum Islam tersebut. Dalam konteks ini, para perumus Perda Syariah mesti mencermati terhadap adanya perbedaan pendapat (madzhab) yang telah menjadi bagian dari pola beragama dan idiologi masyarakat Indonesia.

Proses legislasi secara sosiologis harus memperhatikan tolok ukurnya, pasti tujuannya, selaras dengan kondisi sosio-religius masyarakat yang akan diatur, sehingga tidak terjadi multi-tafsir. Dengan ditetapkannya penilaian hukum yang jelas, berarti pembuat undangundang sudah mengantisipasi akibat legislasi, tidak ambigu bagi suatu golongan, karenanya harus mengeliminasi prinsip-prinsip subyektif dari kepentingan-kepentingan politik kekuasaan, agar produk konstitusi yang dihasilkan terlepas dari manipulasi atau penyelewengan kelompok kepentingan (Sirajuddin, 2008: 35).

Prinsip obyektifitas tersebut, menjadi kepastian untuk upaya rekayasa sosial (social engineering), menuju sebuah tatanan masyarakat madani, artinya dengan undang-undang tersebut tidak sekedar mengukuhkan pola-pola kebiasaan dan tingkah laku yang hidup dalam masyarakat yang ada, melainkan juga untuk mengarahkannya kepada tujuan-tujuan yang dikehendaki, menghapuskan kebiasaan yang sudah tidak sesuai, dan menciptakan pola-pola baru yang lebih selaras dengan perkembangan masyarakat. Bila proses pembuatan undangundang sudah cukup matang, hal penting lainnya adalah "upaya penegakan hukum" (law inforcement). Bagian ini terdiri dari upaya menyiapkan komponen birokrasi penegakan hukum, termasuk jenis pengadilan dan proses peradilannya masing-masing.

Kajian filosofis, metodologis yang mendalam sebagai naskah akademik harus dilakukan, dengan melibatkan sebanyak mungkin ahli dari berbagai disiplin keilmuan, baik oleh anggota 
DPR/D maupun para pakar dan akademisi. Hal ini dilakukan untuk memperoleh koherensi dan harmoni antara karakter substansi hukum dengan karakter dan struktur masyarakat yang akan diatur dengan undang-undang tersebut. Sehingga undang-undang yang dihasilkan koheren antara das sollen dengan das seinnya, dapat mewujudkan sebuah tatanan masyarakat yang tertib, adil, tenteram, aman dan sejahtera (mașlạ̣aḥ).

Disadari bahwa suatu tatanan dalam masyarakat yang mampu menciptakan hubunganhubungan yang tetap dan teratur antar anggota masyarakat, tidak hanya terdiri dari satu norma yang tunggal, ia terdiri dari suatu kompleks tatanan (norma). Dalam ilmu hukum dikenal adanya tiga tatanan (norma), yaitu norma kebiasaan yaitu kebiasaan atau kenyataan tingkah laku masyarakat, norma kesusilaan yaitu norma ideal yang harus diwujudkan dalam masyarakat, termasuk norma agama sebagai ius constitudum (Sirajuddin, 2008: 17), dan norma hukum yaitu norma yang sengaja diciptakan untuk tujuan tertentu. Legislasi berarti sebuah proses mengintegrasikan norma kebiasaan yang telah menjadi kaidah berperilaku bagi masyarakat dengan norma kesusilaan (termasuk norma agama) yang diyakini oleh umat Islam sebagai norma yang melegalisasi suatu perilaku, oleh suatu badan atau sekelompok orang yang berkompeten, melalui mekanisme kerja tertentu, menjadi norma hukum yang mengikat seluruh warga masyarakat itu.

Dalam proses legislasi inilah, terdapat peluang mencari titik temu antara norma kebiasaan suatu masyarakat dengan norma-norma kesusilaan (dalam hal ini konsep-konsep mașlaḥạ̣) yang telah banyak dirumuskan oleh para fuqaha, menjadi fundamen-fundamen tatanan sosial yang bisa memenuhi rasa keadilan dan kemaslahatan. Perilaku dan sikap anggota masyarakat sebagai pendukung fundamen tatanan sosial, bukan hanya ditentukan kekuatan kekuasaan dan pemaksaan oleh hukum itu, menurut Hobbes (Rawls, 2006: 305) atau karena kontrak pertemuan antar berbagai kepentingan dalam pandangan John Locke dan Adam Smith (Friedmann, 1996: 79), tetapi juga ditentukan oleh nilai dan norma-norma tertentu yang berasal dari sumber tertinggi yang disebutnya the ultimate reality, menurut Parson (Giddens, 2008: 107).

Sebelum Parson merumuskan teori tersebut, Emile Durkheim, Max Weber dan Vilfredo Pareto telah menunjukkan bahwa eksistensi masyarakat ditentukan oleh sistem nilai, kultur dan norma yang bertautan. Tindakan-tindakan individual bisa saling harmonis di antara mereka sendiri karena "agen-agen sosial” beraksi dengan mengintegrasikan nilai dan norma 
ljtihad, Jurnal Wacana Hukum Islam dan Kemanusiaan, Vol. 11, No. 1, Juni 2011: 21-39

dalam masyarakat (Salim, 2002: 38-65). Demikianlah cara sosiologi memecahkan permasalahan tentang tatanan sosial. Dalam The Social System dan karya lain yang merupakan kelanjutannya, Parsons hendak mempertahankan sebuah visi tentang masyarakat "yang sistemik" dan "fungsional” (Robertson, 1995: 53-61).

Agar sebuah masyarakat stabil bisa tetap bertahan, maka beberapa fungsi di dalamnya harus disinergikan, misalnya fungsi adaptasi (adaptation) terhadap lingkungannya yang menjamin kelangsungan hidup masyarakat tersebut lebih stabil, untuk kemudian mewujudkan tujuan (goal atau sasaran) sebab suatu sistem hanya akan berfungsi jika diorientasikan menuju ke suatu tujuan; integrasi (integration) para anggota masyarakat dan norma-norma yang diakomodasi; dan akhirnya terpeliharanya pola dan norma (pola yang tersembunyi atau latent pattern), yang di pendekkan menjadi AGIL (A: adaptation; G: goal ; I: integration; dan L: latent pattern) (Beilharz, 2003: 297-300).

Teori skema sibernika Parsons ini menunjukkan bahwa manusia dikontrol oleh arus-arus informasi tertentu yang diterimanya dari sumber tertinggi, yang disebutnya sebagai the ultimate reality. The ultimate reality dalam teori skema AGIL muatannya bisa diisi dengan norma tertinggi dalam perspektif Islam, yaitu norma yang datangnya dari Allah swt. yang terkandung dalam konsep mașlạ̣ạ̣ sebagai norma kesusilaan.

Dalam perkembangannya, teori skema sibernika Talcott Parsons ini dielaborasi oleh Prof. Satjipto Rahardjo dalam bukunya "Ilmu Hukum" bahwa the ultimate reality sebagai "kebenaran sejati", merupakan sumber tertinggi yang mengalirkan nilai-nilai yang mengontrol manusia dalam bermasyarakat. Perilaku manusia yang dikontrol oleh the ultimate reality ini akan melahirkan kesadaran diskriminatif pada diri mereka, yaitu kesadaran membedakan mana yang boleh dan tidak boleh dilakukan. Nilai-nilai ini juga memberikan suatu pengertian tentang hal-hal apa saja yang patut dihormati dan oleh karenanya juga harus diwujudkan dan dipelihara (Rahardjo, 1996: 23-24).

Teori tersebut menyarankan perlunya pendekatan dan metodologi baru dalam memahami hukum Islam sebagai bagian dari keberagamaan maysrakat untuk mewujudkan suatu masyarakat yang siap menerima beban (taklif), dan sekaligus menyadari pentingnya beragama (secara kritis, bisa memanfaatkan teori konstruksi sosial yang dikembangkan oleh Peter L. Berger dan Thomas Luckmann, menjadi satu bahasan tersendiri). Agama dalam pengertian 
Legislasi hukum Islam dalam perspektif produk perundang-undangan di Indonesia:... (Mudzakir)

normatif-doktrinal adalah berupa wahyu atau ajaran transendental yang kebenarannya bersifat transendental (untestable truth). Hukum Islam sebagai bagian dari respon terhadap wahyu menduduki kawasan empirik-historis (Rahman, 1979: 102), yang bersifat subyektif, sosiologis dan temporer, memungkinkan adanya titik temu antara the ultimate reality dengan norma kesusilaan secara sosiologis di tengah masyarakat.

Titik temu antar norma ini merupakan proses krusial tetapi sekaligus sebagai core problem tulisan ini untuk menuju desain suatu masyarakat yang harmoni, masyarakat sebagai sebuah sistem, yang terdiri berbagai sub-sistem yang saling terkait. Untuk itu bila dideskripsikan dengan skema AGIL, dalam sebuah masyarakat terdapat sejumlah sub-sistem, maka subsistem the ultimate reality atau iman berfungsi mendorong dan mengendalikan perilaku, subsistem ekonomi berfungsi melakukan adaptasi, sub-sistem politik bertugas memberi definisi tujuan bermasyarakat, sub-sistem kultural (agama, pendidikan) bertugas mendefinisikan, menginternalisasikan dan memelihara norma-norma dan nilai itu, dan terakhir sub-sistem sosial dan hukum (Islam) yang bertugas sebagai harmonisasi sosial (maslahah 'ammah).

\section{Penutup}

Hukum Islam sebagai bagian keberagamaan secara utuh, aktualisasinya harus secara simultan dengan aspek keberagamaan lainnya, seperti aqidah, akhlak, tasawuf dan pranata sosial. Dengan begitu, berpolemik tentang formalisasi hukum Islam menjadi sebuah produk perundang-undangan, tanpa dibarengi penguatan aspek lainnya secara utuh dan mendalam, hanya akan menimbulkan problem keberagamaan bagi umat Islam sendiri, dan bahkan menambah problem baru dalam konteks bermasyarakat, berbangsa dan bernegara di Indonesia, yang secara defakto-empiris umat Islam cenderung berpikir parsial dan dangkal.

\section{Daftar Pustaka}

Abdullah, M. Amin. Studi Agama: Normativitas atau Historisitas. Yogyakarta: Pustaka Pelajar, 1996.

Adji, Oemar Seno. Peradilan Bebas Negara Hukum. Jakarta: Erlangga, 1980.

Audah, Jasser. Maqāsid al-Shari ah as Philosophy of Islamic Law. London-Washington: The IIIT Press, 2008.

Ayubi, Nazih. Political Islam: Religion and Politics in the Arab World. London and New York: Routlegde, 1991. 
Ijtihad, Jurnal Wacana Hukum Islam dan Kemanusiaan, Vol. 11, No. 1, Juni 2011:21-39

Azizy, A. Qodri. Eklektisisme Hukum Nasional: Kompetisi antara bukum Islam dan bukum Umum. Yogyakarta: Gama Media, 2002.

Beilharz, Peter. Teori-Teori Sosial: Observasi Kritis terhadap Para Filosof Terkemuka. Yogyakarta: Pustaka Pelajar, 2003.

Boland, B.J. Pergumulan Islam di Indonesia 1945-1970. alih bahasa oleh Safroedin Bahar, Jakarta: Grafiti Pers, 1985.

Djamil, Fathurrahman. Filsafat Hukum Islam. Jakarta: Logos Wacana Ilmu, 1997.

Friedmann, W. Teori dan Filsafat Hukum: Telaab Kritis atas Teori-Teori Hukum. alih bahasa oleh Uzair Fauzan dan Heru Prasetyo, Jakarta: Raja Grafindo Persada, 1996.

Fuad, Mahsun. Hukum Islam Indonesia: Dari Nalar Partisipatoris Hingga Emansipatoris. Yogyakarta: LKiS: 2005.

al-Ghazali, Abu Hamid. Al-Mustasfa min Tlm al-Ușūl. Vol. 2, Bairut: Dār al-Fikr, 1994.

Gibb, H.A.R. (ed.). Wither Islam? A Survey of Modern Movement in the Moslem World. London: Victor Gollacz Ltd., 1932.

Giddiens, Anthony (et.al). Sosiologi Sejarah dan Berbagai Pemikirannya. alih bahasa oleh Ninik Rochani Sjams, Yogyakarta: Kreasi Wacana, 2008.

Halim, Abdul. Politik Hukum Islam di Indonesia. Jakarta: Badan Litbang dan Diklat Departemen Agama RI, 2008.

Hasan, Ahmad. Pintu Ijtihad Sebelum Tertutup. alih bahasa oleh Agah Garnadi Bandung: Penerbit Pustaka, 1994.

Hendropuspito, D. Sosiologi Agama. Yogyakarta: Kanisius, 2000.

al-Bukhary, Muhammad Isma'il. Șạ̣ị̣. Vol. II, Singapura: Maktabah wa Mațba'ah Sulaiman Zamar'i, t.th.

Johnson, Doyle P. Teori Sosiologi Klasik dan Modern. alih bahasa oleh Robert M.Z. Lawang, Jakarta: PT. Gramedia, 1988.

Rawls, John. Teori Keadilan Dasar-Dasar Filsajat Politik untuk Mewujudkan Kesejabteraan Sosial dalam Negara. alih bahasa oleh Uzair Fauzan dan Heru Prastyo, Yogyakarta: Pustaka Pelajar, 2006.

Kuswanjono, Arqom. Integrasi Ilmu dan Agama. Yogyakarta: Kahfi Ofset, 2010.

Mahfud. Moh. MD. Politik Hukum di Indonesia. Jakarta: PT. Raja Grafindo Persada, 2010.

Mawardi, Ahmad Imam. Fiqh Minoritas: Fiqh Al-Aqalliyat dan Maqashid Al-Syariah: Dari Konsep ke Pendekatan. Yogyakarta: LkiS, 2010.

Mertokusumo, Sudikno. Mengenal Hukum. Yogyakarta: Liberty, 1999.

Musa, Muhammad Yusuf. Niæăàm al-Hukem fi al-Isläm. Kairo: Dār al-Kitāb al-'Arabī, 1963. 
Legislasi hukum Islam dalam perspektif produk perundang-undangan di Indonesia:... (Mudzakir)

Muslih, Muhammad. Filsafat Ilmu: Kajian atas Asumsi Dasar, Paradigma dan Kerangka Teori Ilmu Pengetabuan. Yogyakarta: Belukar, 2004.

Mustansyir, Rizal dan Munir, Misnal. Fisafat Ilmu. Yogyakarta: Pustaka Pelajar, 2008.

An-Na'im, Abdullahi Ahmed. Dekonstruksi Syariab. alih bahasa oleh Ahmad Suaedy dan Amiruddin Arrani, Yogyakarta: LkiS, 1994.

Noer, Deliar. Gerakan Moderen Islam di Indonesia 1900-1942. Jakarta: LP3ES, 1996.

Parson, Talcot. The Social System. New York: The Free Press, 1996.

Rahardjo, Satjipto. Ilmu Hukum.Bandung: PT. Citra Aditya Bakti, 1996.

Rachman, Budhy Munawar (ed.). Ensiklopedi Nurcholish Madjid. Jakarta: Paramadina. CSL dan Mizan, 2006.

Rahman, Fazlur. Islam. Chicago and London: University of Chicago Press, 1979.

Robertson, Roland (ed). Agama dalam Analisa dan Interpretasi Sosiologi. alih bahasa oleh ahmad Fedyani S., Jakarta: Rajawali Press, 1992.

Sahradi, Jamali. Metodologi Studi Islam: Menelusuri Jejak Historis Kajian Islam ala Sarjana Orientalis. Bandung: Pustaka Setia, 2008.

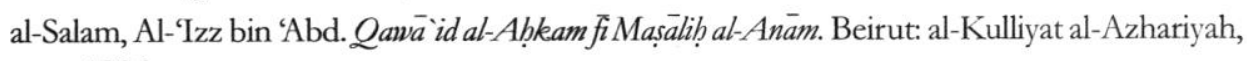
1986.

Saleh, Abdul Mun'im. Hukum Manusia sebagai Hukum Tuban. Yogyakarta: Pustaka Pelajar, Cet. Ke-1, 2009.

al-Sayuthy, Al-Imam Jalal al-Din 'Abd al-Rahman bin Abiy Bakr. Al-Ashbah wa al-Naža' ir fi al-Furū'. Surabaya: Al-Hidayah, 1975.

Schacht, Joseph. An Introduction to Islamic Law. London: Oxford University Press, 1969.

Sirajuddin. Legislasi Hukum Islam di Indonesia. Yogyakarta: Pustaka Pelajar, 2008.

Syamsuddin, M. Din. Islam dan Politik Era Orde Baru. Jakarta: Logos Wacana Ilmu, 2001.

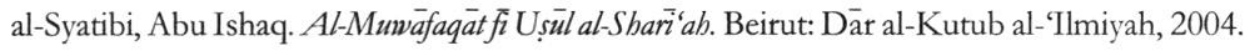

Tafsir, Ahmad. Filsafat Umum: Akal dan Hati sejak Thales sampai James. Bandung: Remaja Rosdakarya, 1992.

Tim Dosen Filsafat Ilmu Fakultas Filsafat UGM. Filsafat Ilmu. Yogyakarta: Liberty, 1996.

Wahid, KH. Abdurrahman (ed.). Ilusi Negara Islam: Ekspansi Gerakan Islam Transnasional di Indonesia. Jakarta: The Wahid Institut, 2009.

Wach, Joachim. Ilmu Perbandingan Agama: Inti dan Bentuk Pengalaman Keagamaan. Alih bahasa oleh Djamannuri, Jakarta: Rajawali Press, 1994. 